\title{
THE PLASMA “AMMONIA" AND GLUTAMINE CONTENT IN PATIENTS WITH HEPATIC COMA ${ }^{1}$
}

\author{
By J. EDWIN SEEGMILLER, ${ }^{2}$ ROBERT SCHWARTZ,2 AND CHARLES S. DAVIDSON \\ (From the Thorndike Memorial Laboratory, Second and Fourth Medical Services [Harvard], \\ Boston City Hospital, and the Department of Medicine, Harvard Medical School, \\ Boston, Mass., and the National Institute of Arthritis and Metabolic Dis- \\ eases, National Institutes of Health, United States Public Health \\ Service, Bethesda, Md.)
}

(Submitted for publication June 16, 1953; accepted March 12, 1954)

Although the clinical state of hepatic coma is well recognized, it has not been associated with any consistent organic lesion of the central nervous system. This has led to the postulation of a biochemical defect to account for the impairment of the central nervous system observed in hepatic coma; however the biochemical nature and the ultimate cause of hepatic coma has not yet been found $(1,2)$. Certain nitrogenous substances given to patients with cirrhosis of the liver have produced a clinical syndrome indistinguishable from spontaneous impending hepatic coma $(3,4)$. These observations suggested that the quantitative determination of substances closely related metabolically to ammonia might provide a better biochemical correlation with the clinical state.

Since glutamine normally comprises fifteen to twenty-five per cent of the total $\alpha$-amino acids of plasma (5) and may be formed metabolically by the combination of glutamic acid and ammonia (6) the plasma concentration of glutamine might reflect some aspects of ammonia metabolism. Using paper chromatography, Walshe (7) has shown that patients in hepatic coma may show increased amounts of glutamine along with other amino acids in urine and plasma and that the glutamine content of cerebrospinal fluid may be elevated.

Quantitative determinations of volatile base ("ammonia"), glutamine, and total $\alpha$-amino nitrogen were performed on the plasma of normal adults and of patients with severe cirrhosis of the

\footnotetext{
1 This work was done under the sponsorship of the Commission on Liver Disease, Armed Forces Epidemiological Board, and was supported in part by the office of the Surgeon General, Department of the Army, and in part by a grant from Merck and Company, Inc., Rahway, N. J., to Harvard University.

2 On assignment from the National Institute of Arthritis and Metabolic Diseases, United States Public Health Service.
}

liver, impending hepatic coma, and hepatic coma. The effect of ammonium chloride administered intravenously on plasma glutamine was also determined.

\section{METHODS AND MATERIALS}

Patients were selected from the wards of the Boston City Hospital and the Metabolic Ward of the Thorndike Memorial Laboratory. Eleven laboratory personnel served as normal controls. The ten patients with cirrhosis were chronic alcoholics who had clinical as well as laboratory evidence of chronic liver disease, i.e., spider angiomata, palmar erythema, palpable liver or spleen, ascites and edema, bromsulfalein retention, serum bilirubin elevation, and abnormal thymol turbidity and flocculation tests. Although oliguria was frequently observed in patients with coma, renal function as judged by azotemia was usually normal except terminally. (see Figures 2 and 3 ). Those thirteen patients classed as impending hepatic coma showed in addition mental confusion, lethargy, and the characteristic tremor described by Adams and Foley (8). "Semicoma" refers to a state of unconsciousness from which patients still could be aroused. Thirteen patients who were comatose generally could not be aroused even by painful stimuli, and often corneal reflexes were absent. Whenever possible, serial observations were made.

\section{METHODS}

Plasma collection. Venous blood was collected with precautions described by Conway and Cooke (9) without stasis in an oiled syringe and transferred immediately to a $\mathrm{CO}_{2}$-filled test tube containing dried heparin $(0.03 \mathrm{mg}$. per cc. blood) and chilled immediately in an ice bath. Plasma was separated by centrifugation in the cold and either assayed immediately or stored in a deep freeze at $-21^{\circ} \mathrm{C}$. Such storage did not change the plasma glutamine content for at least sixty days. In addition proteinfree filtrates of plasma were made without delay after separation and stored in the deep freeze until subsequent analysis for $\alpha$-amino nitrogen.

Assays. Glutamine was determined enzymatically utilizing the specific glutaminase of Clostridium welchii SR-12 (American Type Culture Collection No. 6784) by 
adapting the method of Krebs (10) to use with plasma. The organisms were grown, harvested and washed as described by Meister, Sober, and Tice (11), and suspended in $0.2 \mathrm{~N}$ acetate buffer $\mathrm{pH} 4.9$ to give a total cellular nitrogen content of $4.6 \mathrm{mg}$. per cc. The preparation was stored in $25 \mathrm{cc}$. aliquots at $-21^{\circ} \mathrm{C}$. and the aliquot in current use was stored at $4^{\circ} \mathrm{C}$. Plasma was incubated with and without enzyme and the amide nitrogen liberated as ammonia from glutamine by glutaminase action was determined by a modification of the microdiffusion method of Seligson and Seligson (12). Standard glutamine and blanks for enzyme, glutamine and reagents were run with each set of determinations with the assays accounting for ninety-five to one hundred per cent of the ammonia expected from the total nitrogen content of a standard glutamine solution. Ninety-four per cent recovery of added glutamine was obtained from normal plasma following the addition of $12.5 \mu \mathrm{g}$. glutamine amide- $\mathrm{N}$ per cc. of plasma analyzed. Recovery from abnormal sera was not determined. All determinations were done in duplicate with a maximum difference of 0.4 $\mu \mathrm{g}$. of nitrogen.

For the glutamine assays $5 \mathrm{cc}$. of plasma was adjusted to $\mathrm{pH}$ 4.8-5.0 with $4 \mathrm{~N}$ acetic acid using a Beckman $\mathrm{pH}$ meter. One cc. of plasma mixed with 1 cc. of $0.2 \mathrm{~N}$ acetate buffer $\mathrm{pH} 4.9$ served as plasma blanks. For glutami- nase treatment, $1 \mathrm{cc}$. plasma was mixed with $0.5 \mathrm{cc} .0 .2 \mathrm{~N}$ acetate buffer $\mathrm{pH} 4.9$ and $0.5 \mathrm{cc}$. of Clostridium welchii suspension described above. These mixtures were prepared in $20 \mathrm{cc}$. serum bottles. After a 30-minute incubation in a $38^{\circ} \mathrm{C}$. water bath, the ammonia was liberated from solution by addition of $1 \mathrm{cc}$. of saturated potassium carbonate and collected by microdiffusion into a centrally suspended drop of phosphoric acid. The acid coated a 6 $\mathrm{mm}$. spherical enlargement at one end of a $4 \mathrm{~mm}$. glass rod suspended in the center of the bottle from a one-hole rubber stopper. The rods were stored with the ball portion immersed in 85 per cent orthophosphoric acid and were rinsed thoroughly with distilled water and only the rod portion was dried with a wipette immediately before use. This treatment permitted a uniform liquid film to be left after dipping the ball portion into $1 \mathrm{M}$ phosphoric acid. After microdiffusion for 1 hour with horizontal rotation of the bottles at 34 r.p.m. and $23^{\circ} \mathrm{C}$., the glass rods were removed and the ball portions rinsed thoroughly in $5 \mathrm{cc}$. of distilled water in a Coleman cuvette. One-half cc. of Nessler's solution prepared by the method of Vanselow (13) was added with mixing and the optical density at $500 \mathrm{~m} \mu$ determined after $20 \mathrm{~min}$ utes with a Coleman Jr. Spectrophotometer and compared with simultaneously run ammonium sulfate standards. The plasma blank was used as an estimation of

\section{PLASMA "AMMONIA" AND gLUTAMNNE CONTENT \\ IN NORMAL SUBJECTS AND PATIENTS WITH CIRRHOSIS}

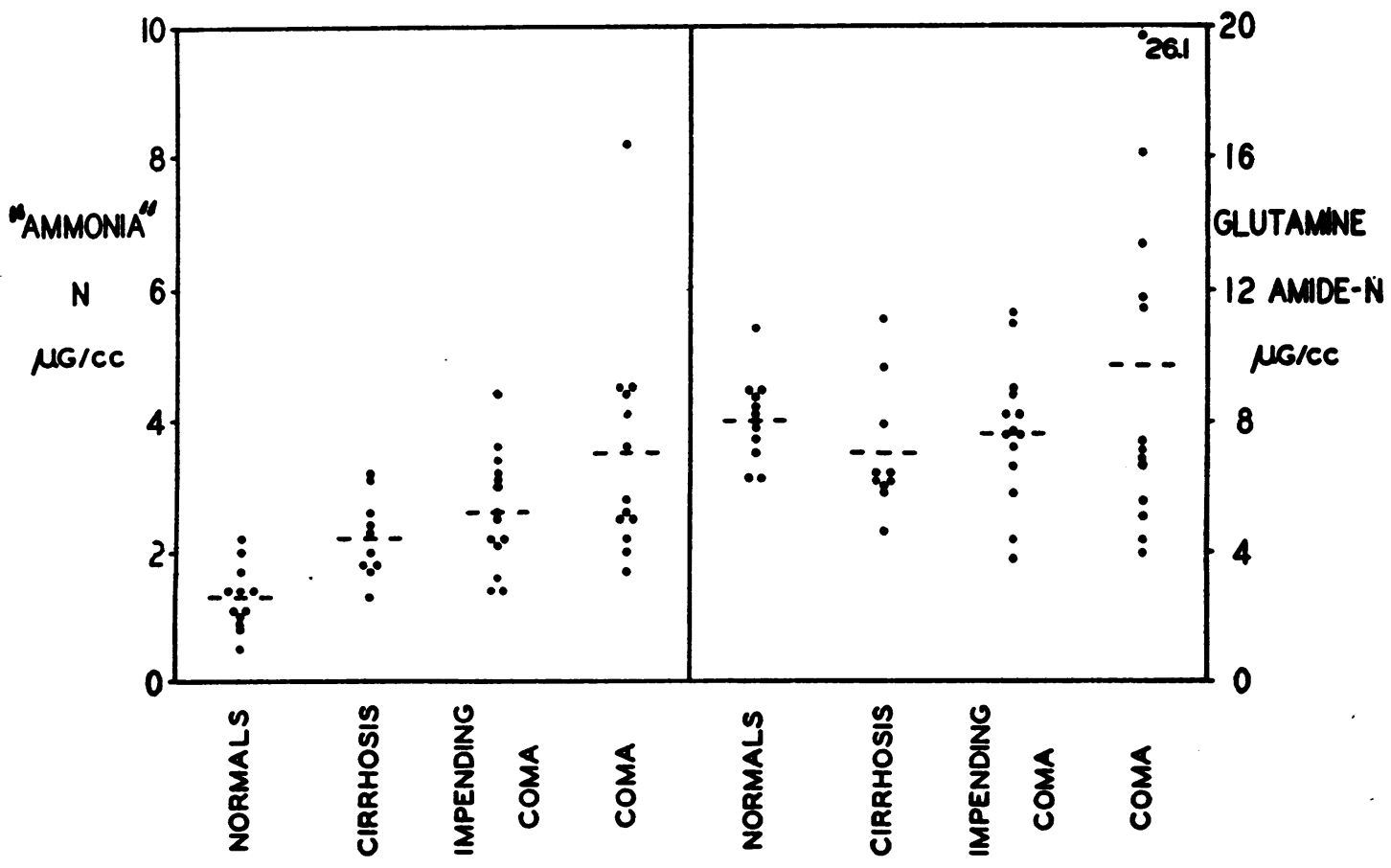

Figure 1 


\section{PLASma}
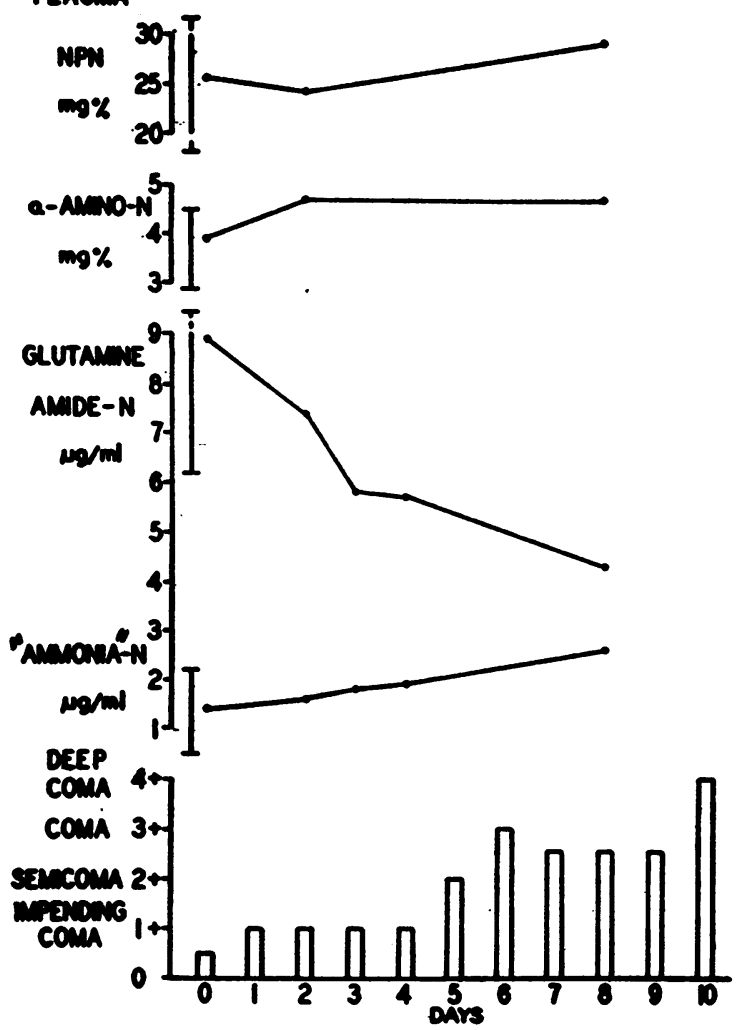

Fig. 2. Serial Observations on Patient A. D. Showing the Relationship of Depth of Coma to the Plasma Nitrogen fractions Measured

The vertical lines indicate the range of normal values. The patient died on the tenth day.

volatile plasma base indicated as "ammonia" in the accompanying charts. This is probably not true ammonia as the values for normal individuals are somewhat higher than are reported in the literature $(9,14)$. Plasma $\alpha$-amino nitrogen was determined by the method of Hamilton and Van Slyke (15).

\section{RESULTS}

The individual values for plasma "ammonia- $N$ " and glutamine amide- $\mathrm{N}$ found in normal controls and patients with liver disease are given in Figure 1. The plasma "ammonia" values show a definite trend toward high values in the coma group. The mean and range of values are : 1.3 (R. 0.52.2) $\mu \mathrm{g}$. ammonia-N/cc. for normals, 2.2 (R. 1.33.2) $\mu \mathrm{g}$. $\mathrm{N} / \mathrm{cc}$. for cirrhosis without neurological complications, 2.6 (R. 1.4-4.4) $\mu \mathrm{g}$. N/cc. for impending coma, and 3.5 (R. 1.7-8.2) $\mu \mathrm{g}$. N/cc. for coma. The scatter of values about the mean for the coma group indicates that half the values are no different from the values found in cirrhosis without neurological complications. The individual values do not consistently correlate with the neurological status.

The glutamine values indicate considerable variation. The mean and range of plasma glutamine values are : 8.04 (R. 6.2-10.8) $\mu$ g. amide- $\mathrm{N} / \mathrm{cc}$. for normal subjects, 7.02 (R. 4.6-11.1) for patients with cirrhosis, 7.66 (R. 3.8-11.3) for patients with cirrhosis with impending coma, and 9.7 (R. 4.0 26.1) for patients with hepatic coma. The patients with impending hepatic coma show values no different from those without neurological complications. Of the thirteen patients in coma, while five had initial glutamine values greater than the

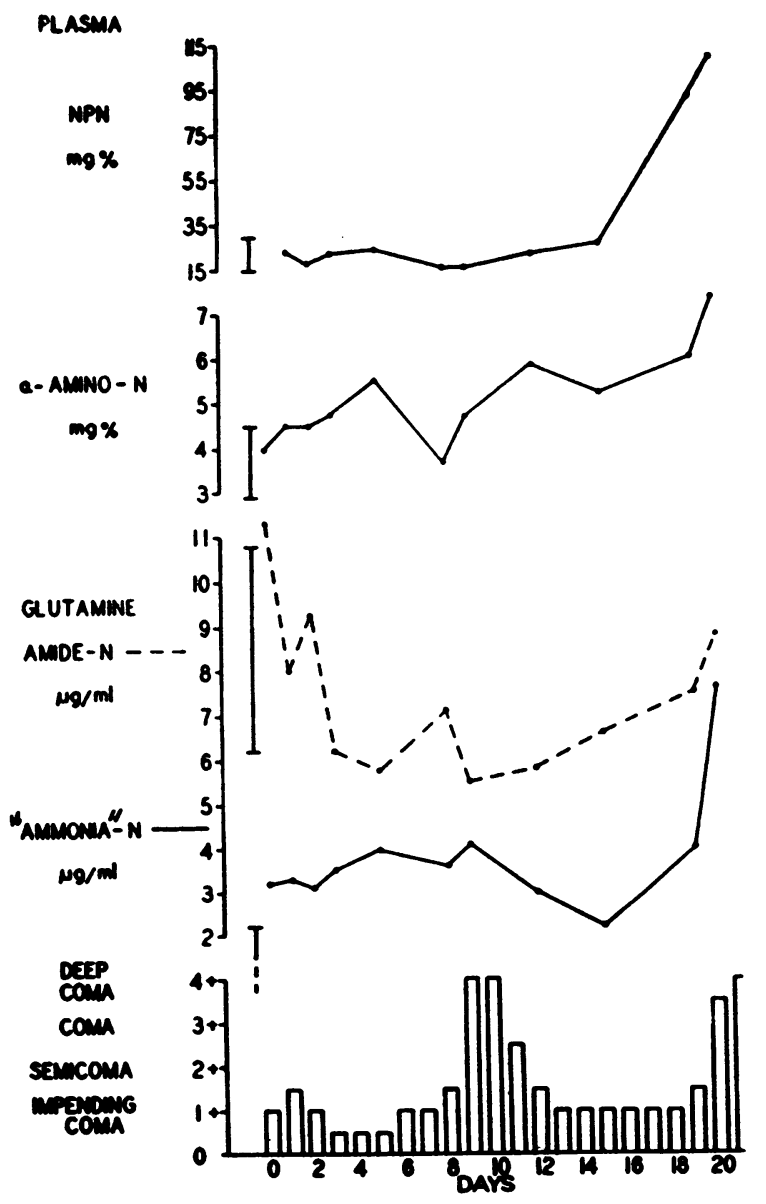

Fig. 3. Serial Observations on Patient $T$. $H$. Showing the Relationship of Depth of Coma to the Plasma Nrtrogen Fractions

The vertical lines indicate the range of normal values. The patient died on twenty-first day of observation. 
normal range, the majority of patients had normal values.

Serial observations have revealed no correlation between neurological status and any fraction of the plasma non-protein nitrogen measured. Two patients followed serially are presented in Figures 2 and 3 . The plasma glutamine data are within the normal range throughout, although in both cases the plasma alpha amino-nitrogen fraction is elevated. In two other patients with coma, elevated plasma $\alpha$-amino $\mathrm{N}$ was noted (values 5.4 and $8.1 \mathrm{mg}$. per cent, the normal range being 2.9-4.5 mg. per cent) with plasma glutamine concentrations of 6.7 and $7.1 \mu \mathrm{g}$. amide $\mathrm{N} / \mathrm{cc}$., respectively, which are within the normal range. There is a suggestive correlation of plasma "ammonia-N" and depth of coma in case 2 (Figure 3 ).

The relationship of plasma (or blood) "ammonia" concentration and neurological status was further evaluated by the intravenous administration of 1 or 2 per cent ammonium chloride in distilled water to four patients with alcoholic cirrhosis of the liver without evidence of impending coma. In six infusions, at a maximal rate of $1100 \mathrm{cc}$. of 2 per cent solution in $2 \frac{1}{2}$ hours, blood or plasma levels as great as $18 \mu \mathrm{g}$. $\mathrm{NH}_{3}-\mathrm{N} / \mathrm{cc}$. (1.8 mg. per cent) were achieved. The characteristic "flapping" tremor and mental confusion of impending coma were observed in only one patient (Figure 4). All patients developed nausea and vomiting at rapid infusion rates (greater than 60 drops per min. of 2 per cent solution). In two cases serial

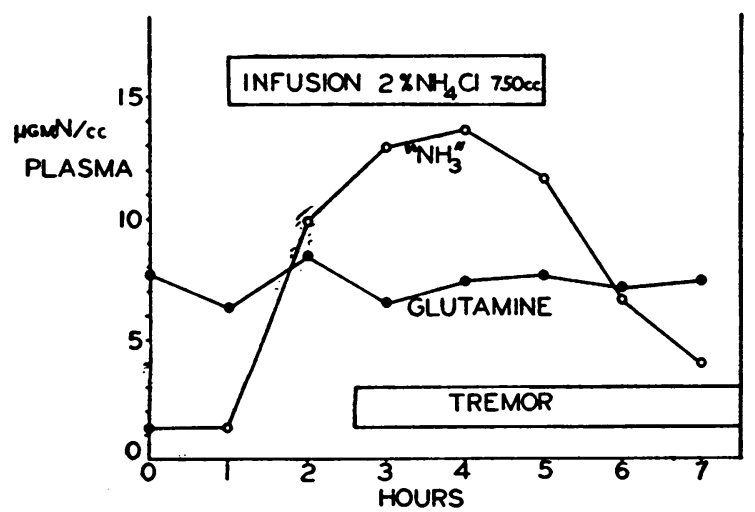

Fig. 4. The Relationship of Plasma Glutamine to "Ammonia" during the Infusion of 2 Per Cent Ammonium Chloride to a Patient with Cirrhosis, Showing Also the Development of the CharacterISTIC TREMOR OF IMPENDING COMA measurements of plasma glutamine indicated stable concentrations throughout although plasma "ammonia" values reached peak levels of 13.6 and $18.4 \mu \mathrm{g}$. ammonia-N/cc. during the infusion.

\section{DISCUSSION}

Studies of ammonia metabolism by Foster, Schoenheimer, and Rittenberg (16) using $\mathrm{N}^{15}$ labeled ammonium ion in the rat have shown that the most rapid incorporation was into an amide nitrogen fraction which is presumably the amide group of glutamine. Incorporation into the $\alpha$-amino nitrogen of glutamic and aspartic acids also occurred but at a much slower rate. This seems to indicate a close metabolic relationship between ammonia metabolism and glutamine, although enzyme studies (17) have not placed glutamine in the direct pathway of reactions leading to the formation of urea which is the main end product of metabolized ammonia. Glutamine formation from ammonia and glutamic acid has been proposed as a biological method for detoxification and transport of ammonia $(18,19)$. A role of metabolic buffer for providing Krebs cycle intermediates has also been proposed (20) and recently evidence for a fundamental role in transfer reactions leading to peptide synthesis has been found (21).

Quantitative determinations of plasma glutamine were made to evaluate the possibility that alterations in plasma glutamine concentration might reflect altered ammonia metabolism. The results do not support this concept. However, it is quite possible that the tissue content of glutamine could be affected by the abnormalities in ammonia metabolism without affecting plasma levels. In hepatectomized dogs, an increased content of glutamine in brain, muscle and plasma has been observed (22). The glutamine content of brain was not proportional to the plasma content.

The failure to observe any relationship between clinical status and plasma glutamine content does not indicate that glutamine-ammonia metabolism is unrelated to the neurological status. Although a better correlation has been observed between plasma "ammonia" and the clinical status, the ammonium infusion studies suggest that a direct quantitative and temporal relationship does not exist. Even though the plasma content of am- 
monia was elevated for several (2 to 4 ) hours, neurological abnormalities were observed in only one patient.

\section{SUMMARY}

The specific glutaminase of $\mathrm{Cl}$. Welchii has been adapted for quantitative analysis of plasma glutamine. Plasma from normal adults and patients with cirrhosis of the liver was assayed for the content of glutamine and volatile base (ammonia) liberated during microdiffusion. The values for plasma glutamine were similar in all groups evaluated. The values for volatile base, "ammonia," tended to be elevated in the impending hepatic coma and hepatic coma groups compared to the controls.

No correlation between plasma glutamine and neurological status of the patients with cirrhosis was noted in individual patients observed serially or in the groups as a whole. A suggestive correlation of neurological status and the plasma "ammonia" is evident in the mean values for the groups; however, this was not consistently present in serial measurements in individual patients.

The characteristic neurological findings of impending hepatic coma were produced in one of three patients in whom elevated plasma "ammonia" levels were produced by the infusion of ammonium chloride without any effect on the concentration of plasma glutamine.

\section{ACKNOWLEDGMENT}

The authors wish to thank Miss Alice Ballou for technical assistance.

\section{REFERENCES}

1. Murphy, T. L., Chalmers, T. C., Eckhardt, R. D., and Davidson, C. S., Hepatic coma : clinical and laboratory observations on forty patients. New England J. Med., 1948, 239, 605.

2. Schwartz, R., Phillips, G. B., Gabuzda, G. J., Jr., and Davidson, C. S., Blood ammonia and electrolytes in hepatic coma. J. Lab. \& Clin. Med., 1953, 42, 499.

3. Gabuzda, G. J., Jr., Phillips, G. B., and Davidson, C. S., Reversible toxic manifestations in patients with cirrhosis of the liver given cation-exchange resins. New England J. Med., 1952, 246, 124.

4. Phillips, G. B., Schwartz, R., Gabuzda, G. J., Jr., and Davidson, C. S., The syndrome of impending hepatic coma in patients with cirrhosis of the liver given certain nitrogenous substances. New England J. Med., 1952, 247, 239.

5. Hamilton, P. B., Glutamine: a major constituent of free $\alpha$-amino acids in animal tissues and blood plasma. J. Biol. Chem., 1945, 158, 397.

6. Krebs, H. A., Metabolism of amino acids. IV. The synthesis of glutamine from glutamic acid and ammonia, and the enzymatic hydrolysis of glutamine in animal tissues. Biochem. J., 1935, 29, 1951.

7. Walshe, J. M., Observations on the symptomatology and pathogenesis of hepatic coma. Quart. J. Med., 1951, 20, 421.

8. Adams, R. D., and Foley, J. M., Neurological changes in more common types of severe liver disease. Tr. Am. Neurol. A., 1949, 74, 217.

9. Conway, E. J., and Cooke, R., Blood ammonia. Biochem. J., 1939, 33, 457.

10. Krebs, H. A., Quantitative determination of glutamine and glutamic acid. Biochem. J., 1948, 43, 51.

11. Meister, A., Sober, H. A., and Tice, S. V., Determination of aspartic and glutamic acids by enzymatic decarboxylation. J. Biol. Chem., 1951, 189, 591.

12. Seligson, D., and Seligson, H., A microdiffusion method for the determination of nitrogen liberated as ammonia. J. Lab. \& Clin. Med., 1951, 38, 324.

13. Vanselow, A. P., Preparation of Nessler's reagent. Indust. \& Engin. Chem. (Anal. Ed.), 1940, 12, 516.

14. Kirk, E., Amino acid and ammonia metabolism in liver disease. Acta med. Scandinav., (Suppl.), 1936, 77, 1.

15. Hamilton, P. B., and Van Slyke, D. D., The gasometric determination of free amino acids in blood filtrates by the ninhydrin-carbon dioxide method. J. Biol. Chem., 1943, 150, 231.

16. Foster, G. L., Schoenheimer, R., and Rittenberg, D., Studies in protein metabolism. V. The utilization of ammonia for amino acid and creatine formation in animals. J. Biol. Chem., 1939, 127, 319.

17. Ratner, S., Urea formation in Phosphorus Metabolism, a Symposium on the role of phosphorus in the metabolism of plants and animals, V. 1, Eds., McElroy, W. D., and Glass, B., Baltimore, Johns Hopkins Press, 1951, pp. 601.

18. Van Slyke, D. D., Phillips, R. A., Hamilton, P. B., Archibald, R. M., Futcher, P. H., and Hiller, A., Glutamine as source material of urinary ammonia. J. Biol. Chem., 1943, 150, 481.

19. Weil-Malherbe, H., Significance of glutamic acid for the metabolism of nervous tissue. Physiol. Rev., 1950, 30, 549.

20. Waelsch, H., Schwerin, P., and Bessman, S. P., Function of the system, glutamic acid-glutamine, in brain metabolism. Federation Proc., 1949, 8, 264.

21. Waelsch, H., Glutamic acid and cerebral function. Advances in Protein Chemistry, Vol. VI, New York, Academic Press, 1951, pp. 299.

22. Flock, E. V., Block, M. A., Grindlay, J. H., Mann, F. C., and Bollman, J. L., Changes in free amino acids of brain and muscle after total hepatectomy. J. Biol. Chem., 1953, 200, 529. 